Article

\title{
Lactobacillus reuteri DSM 17938 Protects against Gastric Damage Induced by Ethanol Administration in Mice: Role of TRPV1/Substance P Axis
}

\author{
Ana P. Oliveira ${ }^{1}$, Luan K. M. Souza ${ }^{1}$, Thiago S. L. Araújo ${ }^{1}$, Simone de Araújo ${ }^{1}$, \\ Kerolayne M. Nogueira ${ }^{1}$, Francisca Beatriz M. Sousa ${ }^{1}$, Renan O. Silva ${ }^{2}$, Dvison M. Pacífico ${ }^{3}$, \\ Conceição S. Martins ${ }^{3}$, Gerly Anne de C. Brito ${ }^{3}$, Marcellus H.L.P. Souza ${ }^{2}$ and \\ Jand Venes R. Medeiros ${ }^{1, *(D)}$ \\ 1 Laboratory of Pharmacology of Inflammation and Gastrointestinal Disorders (Lafidg), Federal University of \\ Piauí, Av. São Sebastião, n 2819, CEP 64202-02, Parnaíba, PI, Brazil; apatriciabiomed@gmail.com (A.P.O.); \\ luankelves11@gmail.com (L.K.M.S.); thiago_parnaiba@hotmail.com (T.S.L.A.); \\ simonearaujoufpi@gmail.com (S.d.A.); keerolayne@hotmail.com (K.M.N.); biatrix14@hotmail.com (F.B.M.S.) \\ 2 Department of Physiology and Pharmacology, Federal University of Ceará, CEP 60430-270, Fortaleza, Ceará, \\ Brazil; renan.oliveira25@yahoo.com.br (R.O.S.); souzamar@hotmail.com (M.H.L.P.S.) \\ 3 Postgraduate Program in Morphofunctional Sciences, Department of Morphology, Faculty of Medicine, \\ Federal University Ceará, CEP 60430-170, Fortaleza-CE, Brazil; dvisonpacifico@gmail.com (D.M.P.); \\ concmartins@hotmail.com (C.S.M.); gerlyanneb@hotmail.com (G.A.d.C.B.) \\ * Correspondence: jandvenes@ufpi.edu.br; Fax: +55-86-3323-5406
}

Received: 3 October 2018; Accepted: 20 November 2018; Published: 21 January 2019

\begin{abstract}
This study aimed to evaluate the effect of Lactobacillus reuteri DSM 17938 (DSM) on ethanol-induced gastric injury, and if its possible mechanism of action is related to inhibiting the transient receptor potential vanilloid type 1 (TRPV1). We evaluated the effect of supplementing $10^{8}$ CFU•g body $\mathrm{wt}^{-1} \bullet$ day $^{-1}$ of DSM on ethanol-induced gastric injury. DSM significantly reduced the ulcer area $\left(1.940 \pm 1.121 \mathrm{~mm}^{2}\right)$ with 3 days of pretreatment. The effects of DSM supplementation were reversed by Resiniferatoxin (RTX), TRPV1 agonist ( $3 \mathrm{nmol} / \mathrm{kg}$ p.o.). Substance P (SP) $(1 \mu \mathrm{mol} / \mathrm{L}$ per $20 \mathrm{~g}$ ) plus $50 \%$ ethanol resulted in hemorrhagic lesions, and DSM supplementation did not reverse the lesion area induced by administering SP. TRPV1 staining intensity was lower, SP, malondialdehyde (MDA) and nitrite levels were reduced, and restored normal levels of antioxidant parameters (glutathione and superoxide dismutase) in the gastric mucosa in mice treated with DSM. In conclusion, DSM exhibited gastroprotective activity through decreased expression of TRPV1 receptor and decreasing SP levels, with a consequent reduction of oxidative stress.
\end{abstract}

Keywords: gastritis; alcohol; probiotic; TRPV; neurokinin

\section{Introduction}

Excessive alcohol consumption is an important public health problem, and globally, alcohol ingestion in 2016 was estimated to be $6.4 \mathrm{~L}$ of pure alcohol per person, which is related to risk of developing of several diseases, resulting in some 3 million deaths [1]. High ethanol concentrations present in alcoholic beverages have the capacity to directly injure the mucosa of the gastrointestinal tract, resulting in acute and chronic damage, such as erosive hemorrhagic gastritis and peptic ulcers [2-4]. Since ethanol is one of the most usually accepted and abused psychoactive drugs [1], the gastric injury generated by its abuse is a worrying consequence. 
Acute ethanol administration disrupts the mucus-bicarbonate barrier, reduces antioxidant defenses, modulates the nitric oxide system, and reduces blood flow in the gastric mucosa [5-8]. An important mechanism by which ethanol mediates these harmful actions is through activating the transient receptor potential vanilloid 1 (TRPV1), which is present in the sensory nerves of the stomach [9]. Activating this receptor causes the release of Substance P (SP), which is capable of activating the neurokinin type 1 receptor (NK1) in gastric epithelial cells, and increases the generation of reactive oxygen species (ROS), the main cytotoxic agent of the gastric mucosa [9-11]. ROS cause peroxidation of lipid components in the cell membrane, and with increased amounts of these free radicals, together with antioxidant enzymes inhibition and glutathione depletion, ethanol causes cell damage as one of its main aggressive pathological mechanisms [12,13]. Thus, agents that inhibit the ethanol-mediated free radical generation pathway, such as TRPV1 and NK1 receptor antagonists, have a great potential to protect against ethanol-induced gastric mucosal lesions [9].

With regard to treating this type of injury, proton pump inhibitors are used, which may reduce the absorption of certain nutrients, in addition to other undesirable effects [14]. This motivates the search for optimized therapeutic agents for preventing and treating ethanol-induced injury, and in this context probiotics are potential candidates, because they present several beneficial activities in the gastrointestinal tract with few side effects [15]. In particular, lactic acid bacteria and their products are likely to contribute to the gastroprotective activity in ethanol-induced lesions, since they decrease levels of SP and lipid peroxidation [16-19]. However, there are still few studies on commercially available probiotic strains [20], such as Lactobacillus reuteri DSM 17938 (DSM) [21].

L. reuteri is a gram-positive, heterofermentative bacterium found in the gastrointestinal tract of humans and rodents [22]. This lactobacillus species has been used safely for many years, and many beneficial effects of the gastrointestinal tract have been attributed to DSM, such as reducing childhood colic, protecting against gastroenteritis, and ameliorating constipation and diarrhea [23-26]. The beneficial effects of this strain are mainly due to the production of antimicrobial compounds and stimulation of the immune system [27]. In addition, a recent study demonstrated that the DSM strain exhibits antinociceptive activity via inhibiting TRPV1 receptor expression [28].

This study was designed to evaluate the effect of DSM on ethanol-induced gastric lesions, and to evaluate if its possible mechanism of action is associated to inhibiting TRPV1 and the consequent reduction of SP, thereby minimizing oxidative stress and gastric injury.

\section{Materials and Methods}

\subsection{Materials}

L. reuteri DSM 17938 (Biogaia AB, Stockholm, Sweden) was purchased from Aché Pharmaceutical Laboratories (São Paulo, Brazil). Ethanol, Substance P acetate salt hydrate, Resiniferatoxin (RTX), and non-peptide $\mathrm{NK}_{1}$ tachykinin receptor antagonist (WIN 62,577) were purchased from Sigma Aldrich (St. Louis, MO, USA). The other reagents were of analytical grade bought from standard commercial companies. One milligram of RTX was dissolved in $1 \mathrm{~mL}$ of $95 \%$ ethanol and stored at $-20{ }^{\circ} \mathrm{C}$. When needed, this solution was diluted in $0.9 \%$ saline to the necessary concentration. WIN 62,577 was dissolved in dimethyl sulfoxide (DMSO). The other compounds were dissolved in saline when needed.

\subsection{Animals}

Swiss mice (25-30 g) were maintained at temperature control of $22 \pm 2{ }^{\circ} \mathrm{C}$, under a 12 -h light $/ 12$-h dark cycle, with free access to food and water. The procedures were executed as specified by the Guide for Care and Use of Laboratory Animals (National Institute of Health, Bethesda, MD, USA), and the Ethics Committee in Research of the Federal University of Piauí previously approved all experiments under protocol number 292/17. 


\subsection{Experimental Design on the Ethanol-Induced Gastric Mucosal Damage}

The animals were randomized into groups (5-6 mice per group), with different treatments as follow: Control animals (healthy or injured) were pretreated with saline $(0.9 \%)$ by gavage; the other 3 groups received $10^{8} \mathrm{CFU} / \mathrm{g}$ body wt/day of freeze-dried DSM by gavage for 3, 7, or 14 days, according to previous studies [19]. The mice were deprived of food for $20 \mathrm{~h}$ before the ethanol-induced gastric damage, but had free access to water. After pretreatment, the animals supplemented with DSM and the injured group received ethanol $50 \%(0.5 \mathrm{~mL} / 25 \mathrm{~g}$ p.o.), and the healthy group was treated with saline. After $1 \mathrm{~h}$, the animals were euthanized, their stomachs were removed and opened along the greater curvature, and the gastric damage was measured using ImageJ software (National Institutes of Health, Bethesda, MD, USA), according to Medeiros et al. [29]. Tissues of each stomach were immediately fixed in $10 \%$ formalin for subsequent histopathological analysis. Unfixed samples of gastric mucosa were stored at $-80^{\circ} \mathrm{C}$ for biochemical analysis.

\subsection{Evaluation of the Role TRPV1 and SP in Mediating the Protective Effects of DSM on Ethanol-Induced Gastric Mucosal Damage}

To evaluate the role of the inhibition of TRPV1 in the protective effects of DSM in gastric mucosa, the mice were supplemented with DSM for 3 days, and on the fourth day, the animals received an agonist of TRPV1, RTX ( $3 \mathrm{nmol} / \mathrm{kg})$ orally (p.o.) alongside $50 \%$ ethanol treatment $(0.5 \mathrm{~mL} / 25 \mathrm{~g})$, according to Tramontana et al. [30], to activate the receptor.

To evaluate the possible role of NK1 modulation in gastric protection, a lesion was induced with the intraperitoneal administration of $1 \mu \mathrm{mol} / \mathrm{L}$ per $20 \mathrm{~g}$ of SP acetate salt hydrate, an agonist of the NK1 receptor, immediately before ethanol exposure, according to Karmeli et al. [11]. This lesion was induced after the 3 days of DSM administration in mice, or $30 \mathrm{~min}$ after the intraperitoneal administration of the NK1 antagonist, WIN 62,577 (20 mg/kg i.p.). One hour later, gastric damage was evaluated as described previously.

\subsection{Histopathological Analysis of Gastric Damage}

Photomicrographs of gastric ulcer and scores analysis were done by viewing ulcers with the use of microscope $100 \times$ and $400 \times$ magnification. Gastric ulcer condition was evaluated by the scoring system according to Laine and Weinstein [31].

\subsection{TRPV1 Immunohistochemistry in Gastric Tissue}

The tissue was stained for antigen-antibody complexes using a peroxidase detection system (LSAB kit, DAKO). Sections were rinsed with tris-buffered saline (TBS) buffer and incubated with rabbit polyclonal TRPV1 antibodies diluted 1:1000 overnight at $4{ }^{\circ} \mathrm{C}$. The tissue slides were washed, incubated with a biotinylated secondary antibody (1:400) in phosphate buffered saline/bovine serum albumin (PBS-BSA), washed again, and were incubated with an avidin-biotin-horseradish peroxidase conjugate (by Vectastain) and peroxidase substrate for analysis with the chromogen 3,3'-diaminobenzidine tetrahydrochloride (DAB), which provided the slides the typical brown color of the reaction. The slides were counterstained with Harris's hematoxylin. Negative control sections were processed at the same time as described, but without the TRPV1 antibody [32].

\subsection{Immunohistochemical Analysis}

The images were acquired from a camera with an LAZ 3.5 acquisition system (LEICA DM1000, Wetzlar, Germany) coupled to a light microscope. The resulting microscopic images were subjected to background subtraction and color correction.

The staining intensity of TRPV1 was estimated with ImageJ v1.46 software, according to the qualitative and nonsubjective method described by Helps et al. [33]. Hematoxylin and DAB component vectors were separated in section images, with a final magnification of $100 \times$, by the ImageJ Color 
deconvolution (H-DAB) plugin. This method has demonstrated a linear correlation between increasing antibody concentration and DAB weight (DABwt) [34]. The results are expressed as DABwt $\%$.

\subsection{Enzyme-Linked Immunosorbent Assay (ELISA) for SP}

The SP content in gastric tissue was analyzed by an enzyme immunoassay using a commercially available enzyme immunoassay kit from Cayman Chemicals (Ann Arbor, MI, USA). Tissue preparation and analysis was performed as described by Ma et al. [35].

\subsection{Malondialdehyde Levels}

The concentration of malondialdehyde (MDA) in stomach sample homogenates was measured by the method described by Mihara and Uchiyama [36].

\subsection{Nitrate/Nitrite Levels in Gastric Tissue}

The level of nitric oxide (NO) was measured by quantifying the $\mathrm{NO}$ metabolites nitrate $\left(\mathrm{NO}_{3}{ }^{-}\right)$ and nitrite $\left(\mathrm{NO}_{2}{ }^{-}\right)$in the gastric tissue, according to the method described by Green et al. [37].

\subsection{Reduced Glutathione Assay}

The concentration of reduced glutathione (GSH) in stomach tissues as nonprotein sulfhydryls was estimated using the technique described by Sedlak and Lindsay [38].

\subsection{Superoxide Dismutase Assay}

Superoxide dismutase (SOD) activity was measured using a modified spectrophotometric assay [39]. In this method, enzyme activity is calculated by the amount of SOD capable of inhibiting nitrite formation by $50 \%$. For this, a glandular fragment from each stomach was homogenized in $1 \mathrm{~mL} / 100 \mathrm{mg}$ of tissue phosphate buffer ( $50 \mathrm{nM}, \mathrm{pH} 7.4)$. One hundred microliters of the homogenate were added to $1110 \mu \mathrm{L}$ of phosphate buffer, $75 \mu \mathrm{L}$ of L-methionine $(20 \mathrm{mM}), 40 \mu \mathrm{L}$ of Triton X-100 $(1 \% v / v), 75 \mu \mathrm{L}$ of hydroxylamine chloride $(10 \mathrm{mM})$, and $100 \mu \mathrm{L}$ of ethylenediaminetetraacetic acid (EDTA) $(50 \mu \mathrm{M})$. This solution was incubated in a $37^{\circ} \mathrm{C}$ water bath for $5 \mathrm{~min}$, then $80 \mu \mathrm{L}$ of riboflavin solution $(50 \mu \mathrm{M})$ was added and exposed to light for $10 \mathrm{~min}$. From this solution, $100 \mu \mathrm{L}$ of the sample was withdrawn, and another $100 \mu \mathrm{L}$ of Griess reagent was added to wells, and after $10 \mathrm{~min}$, the absorbance was read at $550 \mathrm{~nm}$ by spectrophotometry on an ELISA reader. In addition, the amount of total proteins was determined with a commercial Labtest kit. The results were expressed as $\mathrm{uSOD} / \mu \mathrm{g}$ of protein.

\subsection{Gastric Wall Mucus}

The determination of mucus content was carried out as described by Corne et al. (1974) after ethanol-induced gastric ulcer [40].

\subsection{Gastric Acid Secretion}

The pylorus ligature method was used to evaluate gastric acid secretion [41]. Initially, mice were supplemented with DSM, saline, or 50\% ethanol p.o. for 3 days. After $24 \mathrm{~h}$ of fasting, the mice were anesthetized intraperitoneally with a combination of xylazine hydrochloride $(5 \mathrm{mg} / \mathrm{kg})$ and ketamine $(60 \mathrm{mg} / \mathrm{kg})$. Saline was injected into the duodenal lumen in mice that received DSM, saline, or ethanol. In another group, omeprazole $(5 \mathrm{mg} / \mathrm{kg})$ was injected into the duodenal lumen as well. After $4 \mathrm{~h}$, animals were euthanized, the stomachs were opened, and the gastric contents were collected. Total acidity of the gastric juice was evaluated with $0.01 \mathrm{~N} \mathrm{NaOH}$, using $2 \%$ phenolphthalein as an indicator, and the final volume and $\mathrm{pH}$ were directly measured on the mucosal side of the stomach. 


\subsection{Statistic Analysis}

The results were expressed as mean \pm standard error of mean ( \pm S.E.M.). Statistical analysis was performed using GraphPad Prism statistical software, version 6.0 (GraphPad Software Inc., San Diego, CA, USA). Differences between groups were evaluated using Analysis of Variance (ANOVA) and the Student-Newman-Keuls post hoc test, when appropriate. Moreover, the Kruskal Wallis nonparametric test, followed by Dunn's test, were used in histopathological analyses. Difference between groups were considered statistically significant when $p<0.05$.

\section{Results}

\subsection{Effect of DSM on Ethanol-Induced Gastric Damag}

DSM supplementation significantly prevented ethanol-induced gastric injury. Figure 1 shows macroscopic photographs (B) and examinations (K) of mice treated with only $50 \%$ ethanol ( $0.5 \mathrm{~mL} / 25 \mathrm{~g}$ p.o.), indicating significant gastric damage $\left(19.920 \pm 1.650 \mathrm{~mm}^{2}\right)$, compared to healthy controls (A). DSM pretreatment for 3, 7, and 14 days protected the gastric mucosa from ethanol-induced injury (C, D, E, and $\mathrm{K}$, respectively; $p<0.0001)$. Considering that 3 days of pretreatment with DSM significantly reduced the ulcer area $\left(1.940 \pm 1.121 \mathrm{~mm}^{2}\right)$, all other experimental protocols to study the possible mechanisms of gastric protection were performed with 3 days of pretreatment.

\subsection{Evaluation of the Possible role TRPV1 and NK1 Receptor in the Protective Effects of DSM on Ethanol-Induced Gastric Injury}

To investigate the possible involvement of the TRPV1 receptor in DSM-mediated protection against ethanol-induced acute gastric lesions, the effect of treatment with the TRPV1 agonist, RTX (3 nmol/ $\mathrm{kg}$ p.o.) with ethanol $50 \%$ in animals supplemented with DSM was evaluated. Macroscopic evaluation showed that animals treated with RTX alone and ethanol exhibited lesions of $11.480 \pm 1.003 \mathrm{~mm}^{2}$ (Figure 1F,L), and the effects of DSM supplementation were reversed by RTX $\left(13.800 \pm 2.753 \mathrm{~mm}^{2}\right)$ (Figure 1G,L).

To study the possible role of NK1 receptor inhibition in the gastroprotective effect of DSM, we assessed whether DSM was able to decrease the area of gastric lesions caused by the coadministration of ethanol and SP. SP $(1 \mu \mathrm{mol} / \mathrm{L}$ per $20 \mathrm{~g})$ plus $50 \%$ ethanol resulted in hemorrhagic lesions of $22.930 \pm 2.930 \mathrm{~mm}^{2}$ (Figure $1 \mathrm{H}, \mathrm{M}$ ). DSM supplementation did not significantly reverse the lesion area induced by administering SP and ethanol $\left(17.420 \pm 1.280 \mathrm{~mm}^{2}\right)$, as shown in Figure 1I,M. Treatment with the NK1 receptor antagonist, WIN-62577, did protect the gastric mucosa against the injury caused by coadministering SP and ethanol (Figure 1J,M; $p<0.0001$ ).

\subsection{Histopathological Parameters of DSM on Ethanol-Induced Gastric Damage}

Histological evaluation confirmed that no damage was observed in the gastric mucosa of mice treated with saline alone (Figure 2A,B). Animals treated with 50\% ethanol exhibited damaged gastric mucosa, loss of epithelial cells, edema, and enhanced hemorrhages (Figure $2 \mathrm{C}, \mathrm{D}, \mathrm{K}-\mathrm{N}$ ). DSM supplementation significantly inhibited these deleterious effects of ethanol in the gastric mucosa $(p<0.05$, Figure 2E,F,K-N). Administering RTX with 50\% ethanol in DSM-supplemented animals significantly reversed the protective effects of DSM in the gastric mucosa (Figure 2G,H,K-N). Pretreatment with DSM did not reduce the histopathological alterations resulting from the coadministration of ethanol and SP (Figure $2 \mathrm{I}, \mathrm{J}, \mathrm{K}-\mathrm{N}$ ). These microscopic results agreed with the macroscopic findings. 

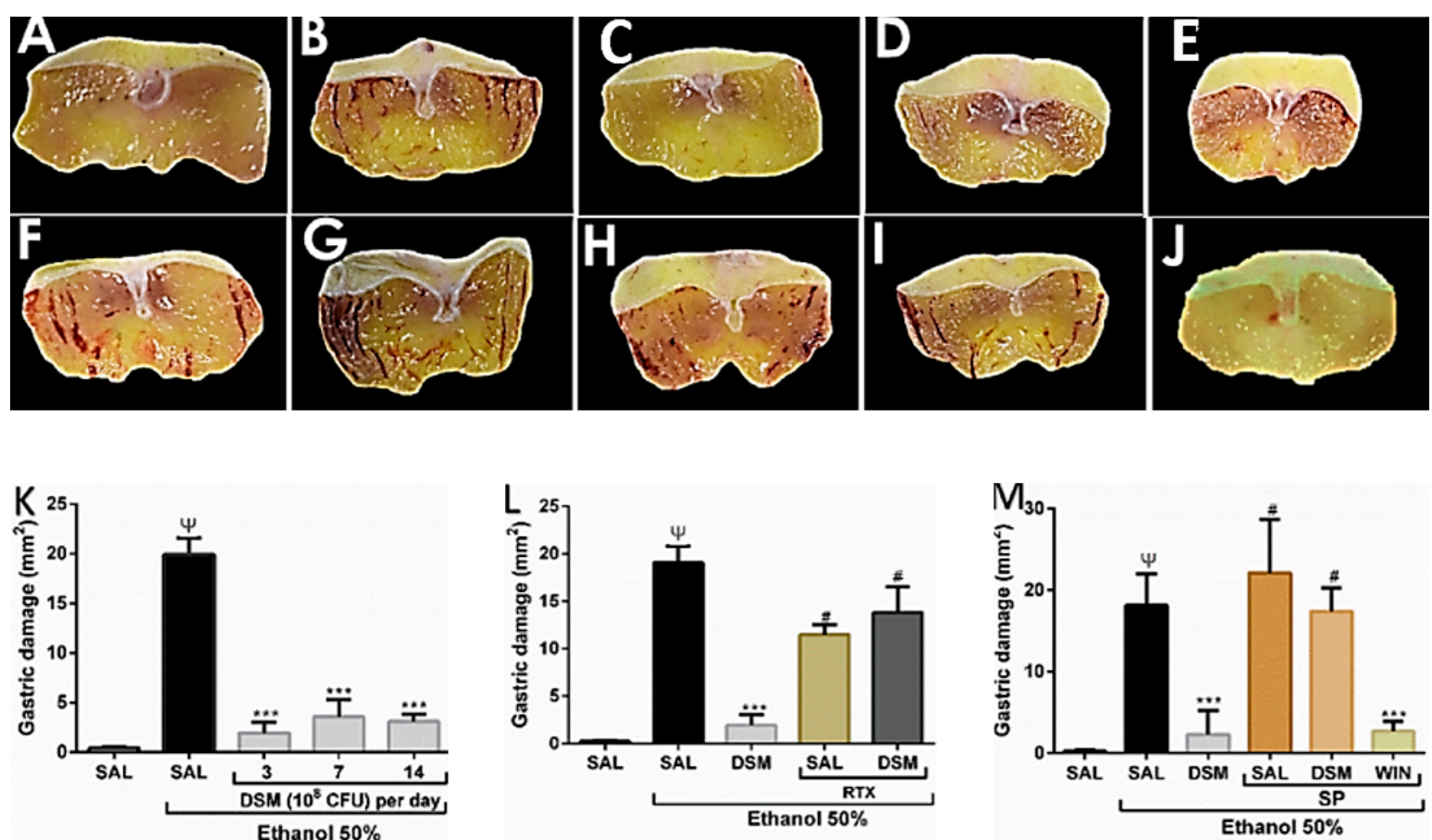

Figure 1. Lactobacillus reuteri DSM 17938 (DSM) supplementation on ethanol-induced gastric damage and the role of the TRPV1/substance P (SP) axis. (A): Healthy group (saline). (B): Injured group (50\% ethanol). (C-E): Mice pretreated with $10^{8} \mathrm{CFU} / \mathrm{g} \bullet b w /$ day DSM for 3 (C), 7 (D), and 14 days (E), followed by ethanol administration. (F): Mice treated with Resiniferatoxin (RTX, $3 \mathrm{nmol} / \mathrm{kg}$ p.o.) and 50\% ethanol. (G): DSM Pretreatment (3 days) in combination with RTX and ethanol treatment. (H): Mice treated with $1 \mu \mathrm{mol} / \mathrm{L}$ per 20 g i.p. (SP) coadministered with $50 \%$ ethanol. (I): DSM supplementation in combination with SP and ethanol treatment. (J): Pretreatment with WIN-62577, an NK1 antagonist, in combination with SP and ethanol. (K): Macroscopic analysis of the gastric injuries upon treatment with ethanol alone and upon pretreatment with DSM. (L): Effects of treatment with RTX and ethanol (50\%) in mice pretreated with DSM. (M): Effects of DSM supplementation on gastric damage induced by the combination of SP and ethanol treatment. The results are the mean \pm S.E.M. of at least 5 mice per group. Results were analyzed using one-way analysis of variance (ANOVA) followed by a Newman-Keuls post hoc test. $\Psi p<0.0001$ versus healthy group; ${ }^{* * *} p<0.0001$ versus injured group; $\# p<0.0001$ versus the DSM-supplemented group.

\subsection{Immunohistochemistry Detection of the TRPV1 Receptor}

The gastric tissues were examined immunohistochemically to determine the localization of the TRPV1 receptor (Figure 3). In the healthy control group (A and B), TRPV1 immunoreactivity was discreet, and the intensity of DAB staining was evident in the gastric mucosa upon ethanol treatment, with marked areas on the epithelium surface and submucosa (C and D). However, lower TRPV1 staining intensity was observed in mice treated with DSM (E and F). As shown in Figure 3G, the color deconvolution analysis of TRPV1 staining confirmed that ethanol treatment significantly increased DAB intensity $(19.750 \pm 2.903 \% \mathrm{DABwt})$, when compared to the saline and DSM groups (9.623 $\pm 1.404 \%$ DABwt; $7.922 \pm 2.046 \%$ DABwt, respectively).

\subsection{SP Levels}

SP levels were significantly reduced in mice pretreated with DSM compared to mice treated with ethanol alone (55.010 $\pm 7.827 \mathrm{pg} / \mathrm{cm}^{3}$ vs. $162.200 \pm 21.090 \mathrm{pg} / \mathrm{cm}^{3}$ respectively; $\left.p<0.05\right)$, as shown in Figure 4. These results suggested that DSM supplementation significantly decreased SP levels in gastric mucosa upon ethanol-induced gastric injury. 

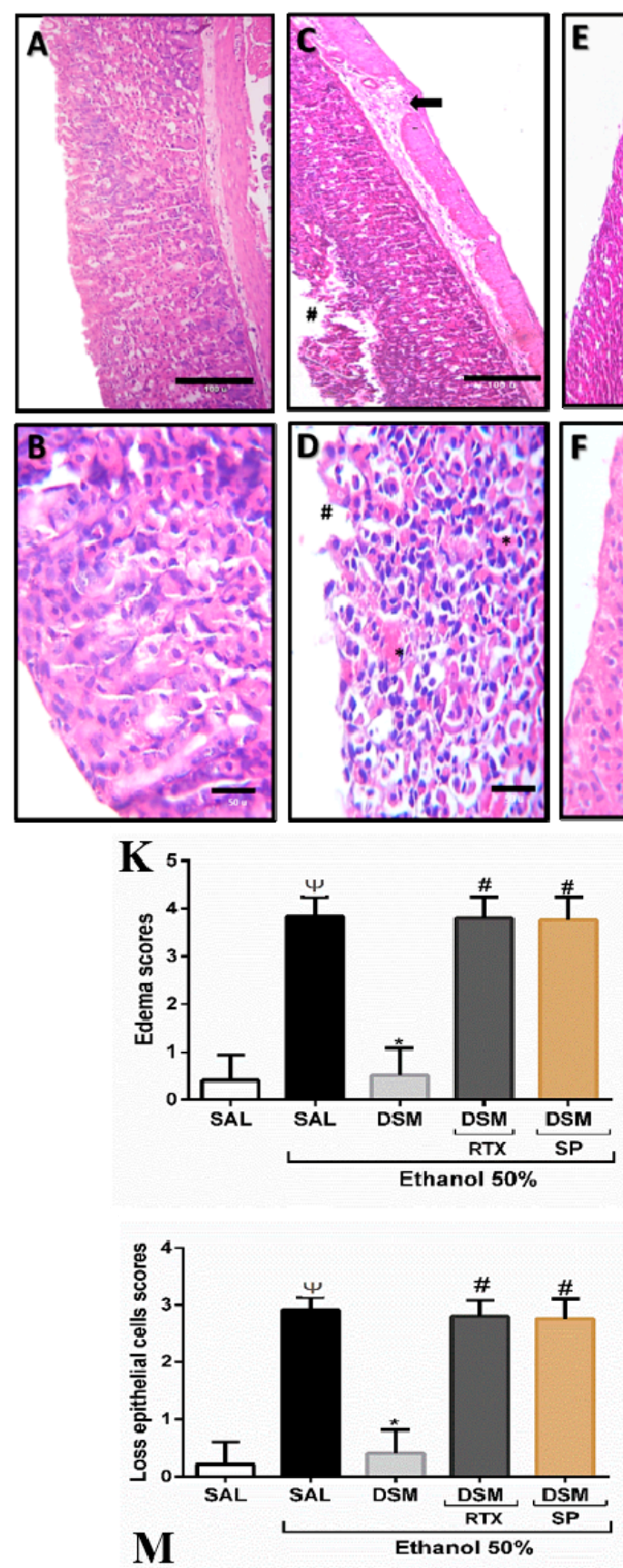
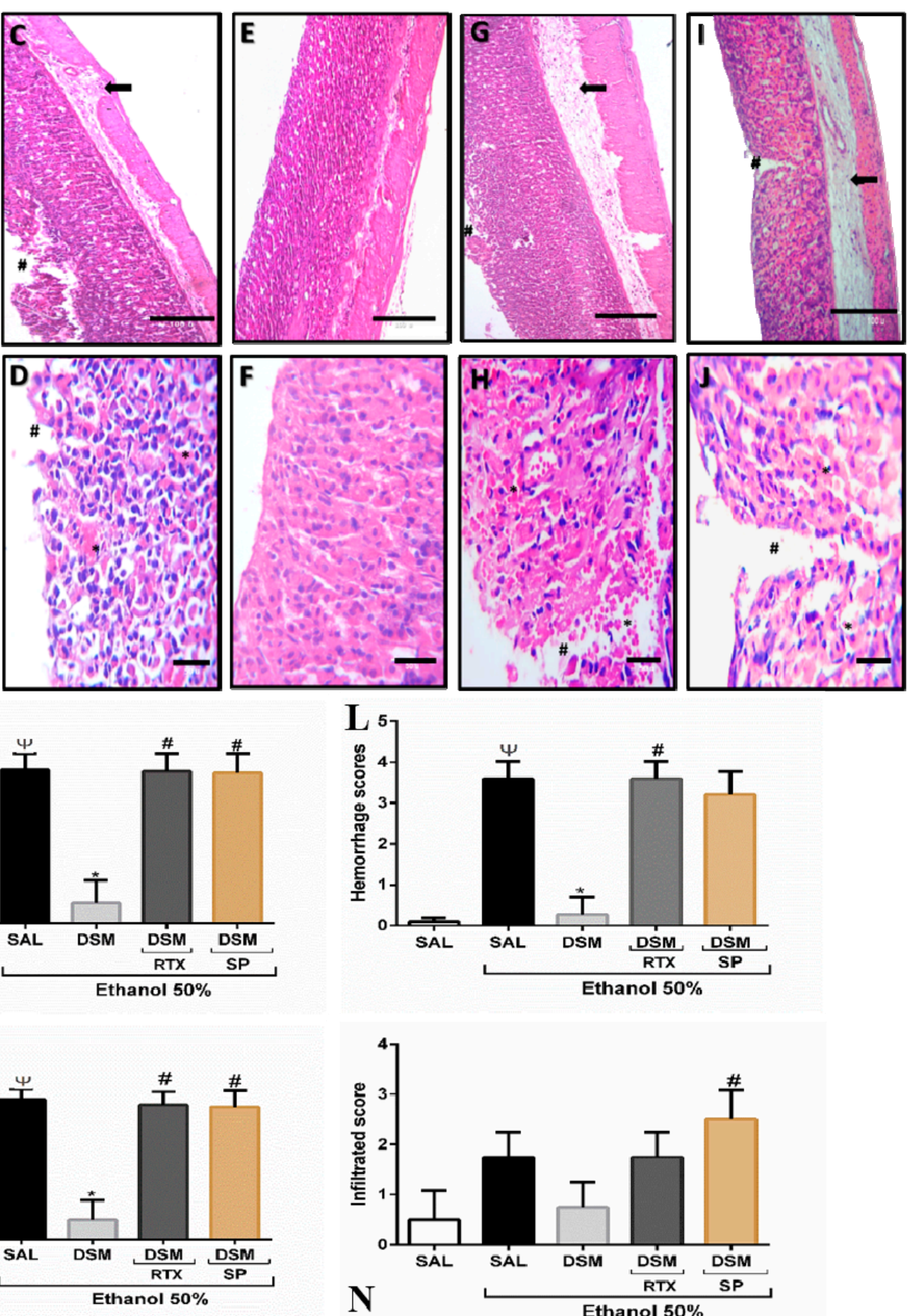

Ethanol 50\%

Figure 2. Histopathological analysis of gastric mucosa. (A-J) Photomicrographs: $100 \times$ magnification for the first line, and 400× for the second line. (A,B): Healthy group. (C,D): Injured group (50\% ethanol). (E,F): DSM supplementation $\left(10^{8} \mathrm{CFU} / \mathrm{g} \bullet \mathrm{bw} /\right.$ day for 3 days) and ethanol administration. $(\mathbf{G}, \mathbf{H})$ : Pretreatment with DSM (3 days) and treatment with RTX and 50\% ethanol. (I,J): DSM supplementation and treatment with $1 \mu \mathrm{mol} / \mathrm{L}$ per $20 \mathrm{~g}$ i.p. of SP and 50\% ethanol. Arrows: Edema; Tags: Epithelial cell loss; Asterisk: Hemorrhage. (K-N): Quantitative analysis of microscopic scores of the gastric mucosa upon ethanol-induced damage (hemorrhage, edema, epithelial cell loss, and infiltration). Results are expressed as mean \pm S.E.M. (5-6 mice per group), and analyzed using Kruskal-Wallis nonparametric tests, followed by Dunn's test. $\Psi p<0.05$ versus healthy group; ${ }^{*} p<0.05$ versus injured group; $\# p<0.05$ versus the DSM-supplemented group. 

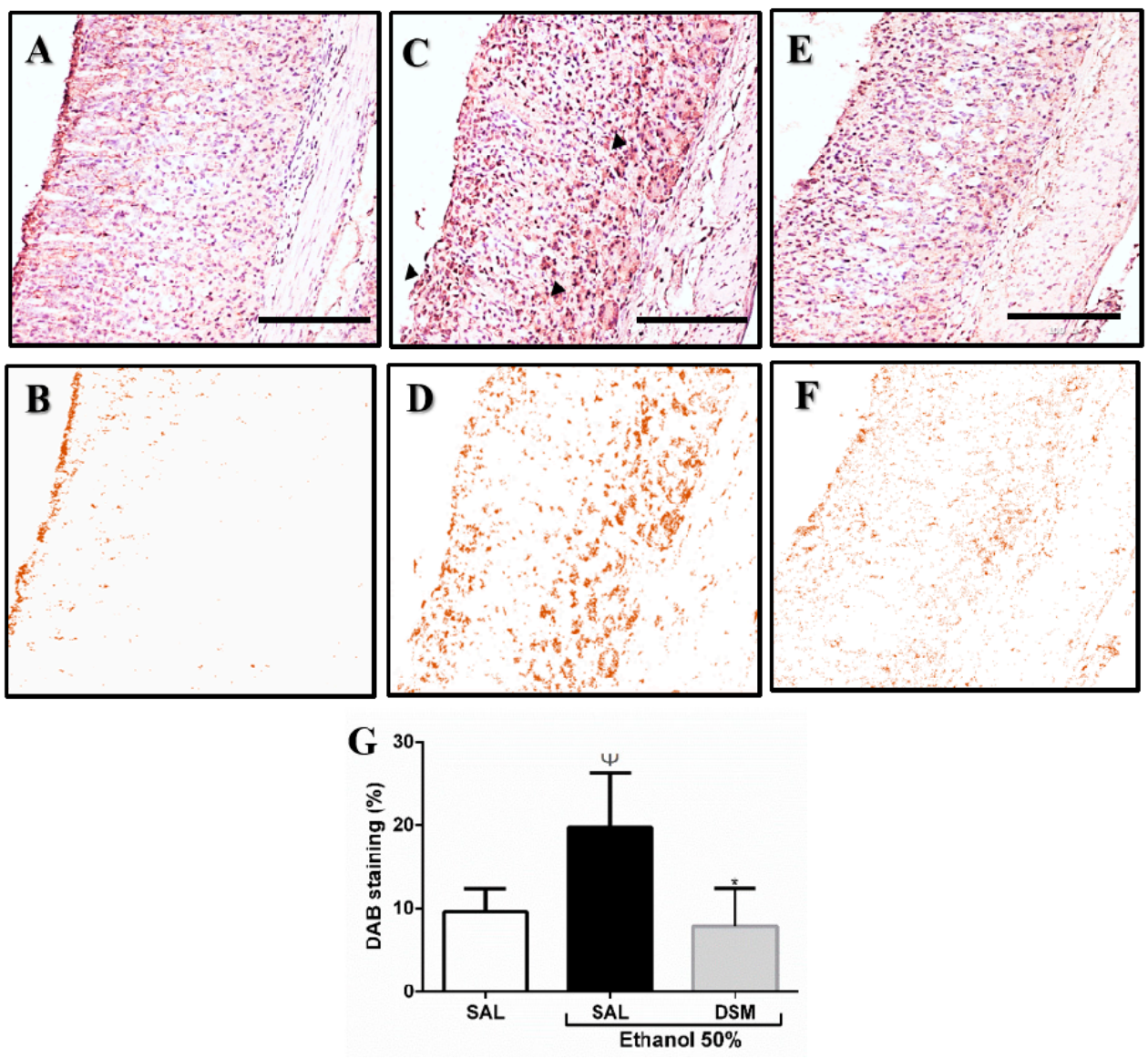

Figure 3. Immunohistochemical analysis of the TRPV1 receptor on the gastric mucosa $(\mathbf{A}, \mathrm{C}, \mathrm{E})$. Diaminobenzidine (DAB) staining by color deconvolution (B,D,F). (A,B): TRPV1 immunoreactivity detected in normal gastric mucosa. (C,D): Increased immunoreactivity of TRPV1 in the ethanol-injured group. (E,F): Decreased immunoreactivity in gastric mucosa of animals pretreated with DSM for 3 days before ethanol-induced gastric damage. $(\mathrm{G})$ : Color deconvolution analysis of DAB staining for TRPV1 in gastric mucosa. One-way analysis of variance followed by a Newman-Keuls post hoc test. $\Psi p<0.05$ versus healthy group; ${ }^{*} p<0.01$ versus injured group. The arrows indicate the increase of marking intensity. Photomicrographs $(100 \times$, scale $100 \mu \mathrm{m})$.

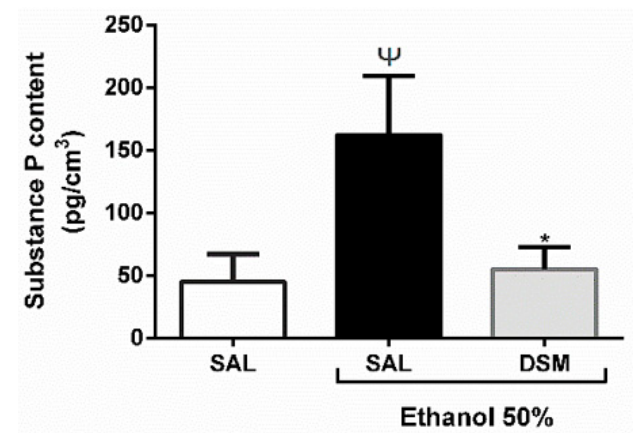

Figure 4. Effects of DSM supplementation on SP contents in gastric mucosa. The amount of SP in gastric mucosa was estimated by enzyme-linked immunosorbent assay (ELISA) and results were expressed as $\mathrm{pg} / \mathrm{cm}^{3}$. Data shown are the mean \pm SEM of at least 5 mice per group. The healthy group was treated with saline only. Ethanol administration significantly increased the gastric concentration of SP. This effect was reverted significantly when the animals were supplemented with DSM ( $10^{8} \mathrm{CFU} / \mathrm{g} \bullet \mathrm{bw} /$ day for 3 days). Results were analyzed using one-way analysis of variance (ANOVA) followed by a Newman-Keuls post hoc test. $\Psi p<0.05$ versus healthy group; ${ }^{*} p<0.05$ versus injured group. 


\subsection{Effect of DSM on Biomarkers of Oxidative Stress and Antioxidant Parameters}

Malondialdehyde, a marker of oxidative stress and a product of lipid peroxidation, was measured to evaluate oxidative stress. Treatment with $50 \%$ ethanol increased the concentration of MDA in gastric mucosa, as shown in Figure 5A (160.400 $\pm 15.210 \mathrm{nmol} / \mathrm{g})$. DSM supplementation significantly reduced the MDA levels in gastric damage induced by ethanol $(74.940 \pm 2.675 \mathrm{nmol} / \mathrm{g})$. In addition, administering RTX with ethanol reversed the protective effect of DSM, and DSM did not decrease MDA levels upon coadministration of SP and ethanol $(152.300 \pm 2.425 \mathrm{nmol} / \mathrm{g}$; $134.800 \pm 29.710 \mathrm{nmol} / \mathrm{g}$ respectively; $p<0.001$ ). Ethanol administration also increased NOx levels (Figure 5B), from levels observed in healthy animals and those pretreated with DSM $(0.105 \pm 0.001 \mu \mathrm{M}$; $0.097 \pm 0.001 \mu \mathrm{M} ; 0.098 \pm 0.001 \mu \mathrm{M}$, respectively). The treatment with RTX also reversed the protective effect of DSM on NOx levels, and DSM pretreatment did not reduce NOx upon SP treatment $(0.103 \pm 0.001 \mu \mathrm{M} ; 0.102 \pm 0.001 \mu \mathrm{M} ; p<0.001)$.
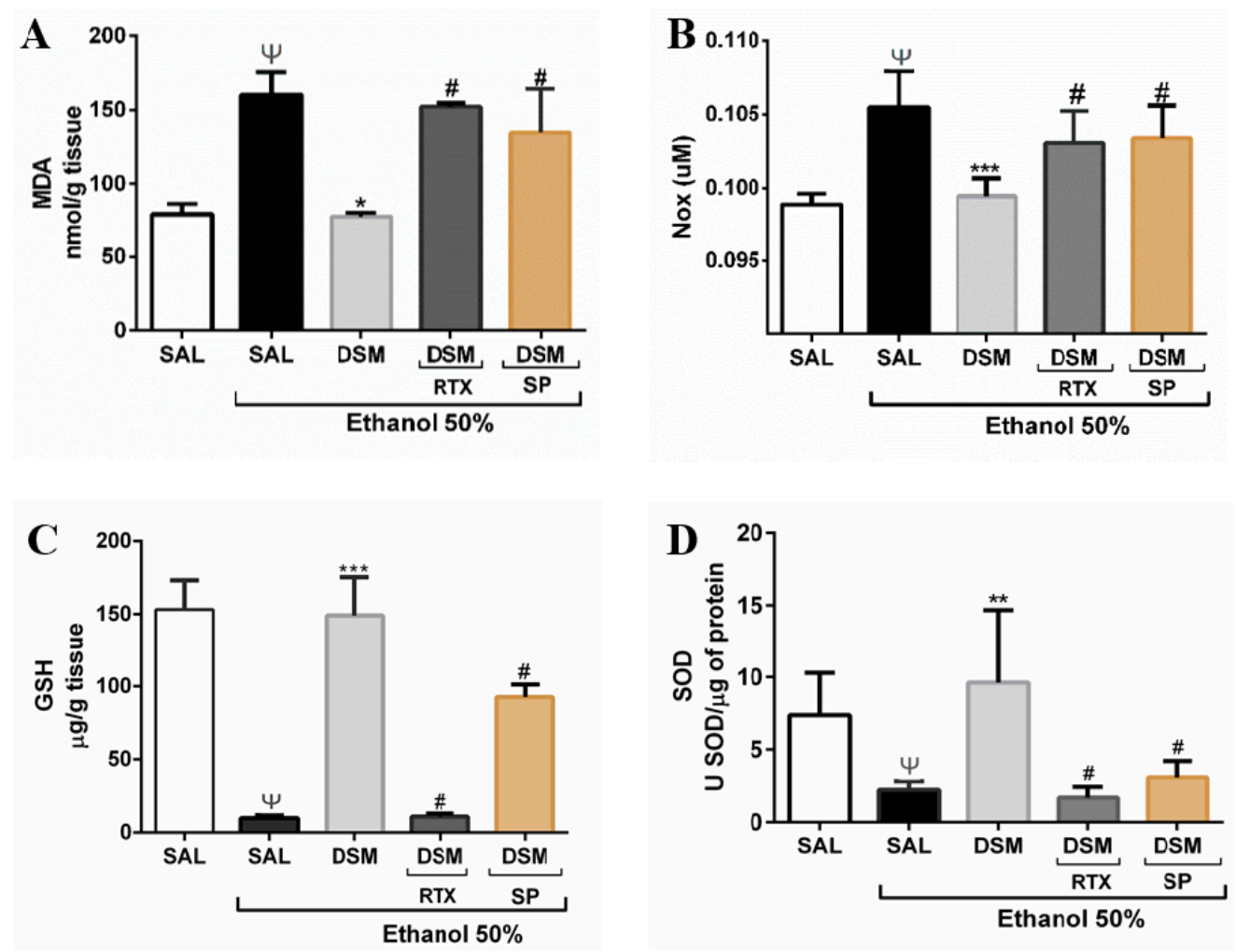

Figure 5. Effects of DSM supplementation on biomarkers of oxidative stress in mice with ethanol-induced gastric damage. Ethanol increased MDA (A) and NOx (B) levels in gastric tissue, but supplementation with DSM $\left(10^{8} \mathrm{CFU} / \mathrm{g} \bullet \mathrm{bw} /\right.$ day for 3 days $)$ significantly prevented this effect. Ethanol administration decreased the gastric glutathione (GSH) concentration (C) and superoxide dismutase (SOD) activity (D). This effect was reverted significantly when the animals were supplemented with DSM. However, administration of RTX with ethanol reversed the protective effects of DSM for all parameters evaluated. Coadministering SP with ethanol overcame the protective effects of DSM. Data shown are the mean \pm SEM of at least 5 mice per group; Results were analyzed using one-way analysis of variance followed by a Newman-Keuls post hoc test. (A): $\Psi p<0.05$ versus healthy group; ${ }^{*} p<0.01$ versus injured group; $\# p<0.001$ versus DSM group; (B): $\Psi p<0.0001$ versus healthy group; ${ }^{* * *} p<0.01$ versus injured group; $\#<<0.001$ versus DSM group; (C): $\Psi p<0.0001$ versus healthy group; ${ }^{* * *} p<0.0001$ versus injured group; $\# p<0.0001$ and $\# p<0.05$ versus DSM group; (D): $\Psi p<0.05$ versus healthy group; ${ }^{* *} p<0.001$ versus injured group; $\# p<0.001$ versus DSM group. 
The GSH concentrations in the gastric mucosa of the five groups are shown in Figure 5C. The normal, baseline level of GSH in the gastric mucosa of animals was $153.300 \pm 20.060 \mu \mathrm{g}$ $\mathrm{GSH} / \mathrm{g}$ tissue. The GSH concentration was significantly decreased (9.923 $\pm 1.931 \mu \mathrm{g} \mathrm{GSH} / \mathrm{g})$ upon administering 50\% ethanol. DSM supplementation maintained the GSH concentration at basal levels $(149.100 \pm 26.330 \mu \mathrm{g}$ GSH/g). RTX administration with ethanol significantly reversed the protective effects of $L$. reuteri. By contrast, DSM did not protect the gastric mucosa upon SP treatment, with GSH reduction $(p<0.0001 ; p<0.05$ respectively). The SOD activity in healthy animals was $7.376 \pm 1.300 \mathrm{uSOD} / \mathrm{mg}$ of protein, and ethanol treatment decreased the SOD concentration in gastric tissue ( $2.240 \pm 0.247 \mu \mathrm{SOD} / \mathrm{mg}$ of protein). DSM increased SOD levels, and this effect was reversed upon RTX administration, and did not increase upon SP treatment $(9.620 \pm 2.918 \mu \mathrm{SOD} / \mathrm{mg}$ protein; $1.700 \pm 0.331 \mathrm{SOD} / \mathrm{mg}$ of protein; $3.090 \pm 0.556 \mu \mathrm{SOD} / \mathrm{mg}$ protein, respectively; $p<0.001)$.

\subsection{Gastric Wall Mucus and Acid Secretion}

As shown in Table 1, administering 50\% ethanol decreased Alcian blue adhesion to the gastric wall mucus, when compared with the amount of dye adhesion in the saline control group $(58.340 \pm 8.941 \mu \mathrm{g} / \mathrm{g}$ tissue; $137.200 \pm 16.580 \mu \mathrm{g} / \mathrm{g}$ tissue, respectively). On the other hand, DSM ( $10^{8} \mathrm{CFU} / \mathrm{g} \bullet \mathrm{bw} /$ day) inhibited this effect of ethanol and rescued gastric mucus adhesion $(103.201 \pm 6.110 \mu \mathrm{g} / \mathrm{g}$ tissue; $p<0.01)$.

Moreover, no significant changes were observed in gastric juice volume, $\mathrm{pH}$, and total acidity, among mice supplemented with DSM, omeprazole, or saline (Table 1). However, ethanol treatment increased these parameters, when compared to levels observed upon saline treatment alone $(p<0.01)$.

Table 1. DSM supplementation $\left(10^{8} \mathrm{CFU} / \mathrm{g} . \mathrm{bw} /\right.$ day for 3 days $)$ on mucus levels and gastric acid secretion in mice.

\begin{tabular}{ccccc}
\hline Treatment & Volume $(\mathbf{m L})$ & $\mathbf{p H}$ (Units) & {$[\mathbf{H + ]}(\mathbf{m E q} / \mathbf{m L} / \mathbf{4} \mathbf{h})$} & $\begin{array}{c}\text { Mucus Levels } \\
\text { (ug/g Tissue) }\end{array}$ \\
\hline Saline & $0.028 \pm 0.02$ & $5.6 \pm 0.2$ & $0.14 \pm 0.02$ & $137.20 \pm 16.58$ \\
Ethanol & $0.350 \pm 0.08^{\Psi}$ & $3.5 \pm 0.2^{\Psi}$ & $3.70 \pm 0.83^{\Psi}$ & $58.34 \pm 8.95^{\Psi}$ \\
Omeprazole & $0.046 \pm 0.02^{* * *}$ & $5.2 \pm 0.5^{*}$ & $0.20 \pm 0.19^{*}$ & - \\
DSM & $0.055 \pm 0.02^{* *}$ & $4.6 \pm 0.5^{*}$ & $0.12 \pm 0.05^{*}$ & $103.20 \pm 6.11^{* *}$ \\
\hline
\end{tabular}

a Data shown are the mean \pm SEM of at least 5 mice per group. ${ }^{\Psi} p<0.01$ versus saline group; ${ }^{*} p<0.05$, ${ }^{* *} p<0.01$, *** $p<0.001$ versus ethanol group. One-way analysis of variance followed by a Newman-Keuls post hoc test. Lactobacillus reuteri DSM 17938 (DSM).

\section{Discussion}

The beneficial effects of probiotics in the GI tract have been demonstrated for various disorders $[19,27,42,43]$. In this study, we investigated the effects of Lactobacillus reuteri DSM 17938 supplementation on the protection of gastric damage induced by $50 \%$ ethanol in mice. Furthermore, we explored the role of the TRPV1/substance P axis in decreasing biomarkers of oxidative stress in gastric mucosa.

DSM, a widely recognized clinical and commercially available Lactobacillus strain $[21,26]$ derived from the L. reuteri strain ATCC 55730 exerts beneficial effects for various GI tract conditions, such as constipation, diarrheal disease, infantile colic, and gastroenteritis [23-26,44], and exhibits immunomodulatory activity [27]. Furthermore, the use of $10^{8} \mathrm{CFU}$ of DSM for 8 weeks results in a high eradication rate of Helicobacter pylori in the gastric mucosa, the main risk factor for developing chronic gastritis [45]. DSM administered at $10^{6} \mathrm{CFU} / \mathrm{g} \bullet \mathrm{bw} /$ day modulates the host mucosal immune system and induces an anti-inflammatory effect in a mouse model of necrotizing enterocolitis [46]. The effects of DSM 17938 on the gastrointestinal tract, in addition to the production of antimicrobial compounds such as reuterine, are mainly due to stimulation of the immune system through modulating dendritic cell responses [27]. In an experimental necrotizing enterocolitis model, this L. reuteri 
strain significantly reduces intestinal inflammation, inhibiting TLR4 and NF-KB receptor expression, in addition to modulating effector and regulatory T cells [46,47].

In our experiments, administering $10^{8} \mathrm{CFU} / \mathrm{g} \bullet \mathrm{bw} /$ day of freeze-dried DSM daily for 3, 7, or 14 days significantly prevented gastric damage induced by $50 \%$ ethanol treatment. These results are in accordance with recent data showing that lactic acid bacteria promote gastric protection against various harmful agents [17-19,48]. Rats pretreated with $2 \times 10^{9} \mathrm{CFU} / \mathrm{d}$ of Lactobacillus rhamnosus GG for 3 consecutive days exhibited enhanced gastric mucosal integrity upon acute damage induced by ethanol [48]. Additionally, mice pretreated with $10^{9} \mathrm{CFU} / \mathrm{kg} \bullet \mathrm{bw}$ of Lactobacillus fermentum for 14 days also exhibited decreased $\mathrm{HCl}$ /ethanol-Induced gastric injury through its antioxidant effect [19].

In agreement with macroscopic findings, ethanol treatment directly injured the stomach mucosa, resulting in hemorrhagic lesions that caused edema, subepithelial hemorrhages, and cellular exfoliation with rupture of the mucosa [49]. In addition, treatment with L. reuteri significantly decreased these histopathological parameters, confirming its protective effect on the gastric mucosa. These results demonstrate an effect of DSM or its bacterial products on the gastric mucosa, which may have occurred because it presents acid and bile tolerance and mucus binding, facilitating its localization and protective action in the gastrointestinal tract [21].

Increased production of free radicals, such as reactive oxygen and nitrogen species, is related to the pathogenesis of ethanol-induced gastric mucosal damage, which damages important biomolecules, injures membranes, and causes cell death and epithelial loss [50]. These radicals cause peroxidation of the lipid components in the cell membrane, and the lipid peroxides are metabolized by $\beta$-oxidation to malondialdehyde, an important indicator of tissue damage by free radicals [13]. Moreover, increasing concentrations of these free radicals, along with inhibition of antioxidant enzymes and glutathione depletion, cause damage and cell death [51]. Gazzieri et al. [9] showed that activation of the TRPV1 receptor by ethanol in the nerve endings of the mucosa causes the release of SP and ROS generation, by a mechanism dependent on the TRPV1 receptor and the NK1 receptor, which mediates the effects of SP. Thus, substances that act as antagonists of these receptors have great potential for preventing and treating gastric lesions generated by alcohol.

Moreover, Perez-Burgos et al. [28] recently showed that DSM inhibits TRPV1 receptor expression, a mechanism involved in its antinociceptive activity in rodents treated with $1 \times 10^{9} \mathrm{CFU}$ for 9 days. Therefore, we evaluated the potential involvement of TRPV1 in the protective effect of DSM against ethanol-induced injury. For this, we activated the TRPV1 receptor with its specific agonist RTX in the gastric lesion in conjunction with ethanol treatment and found that RTX treatment blocked the gastroprotective activity of DSM. Histopathological findings corroborated these results. The immunohistochemistry results demonstrated decreased expression of this receptor in the gastric mucosa upon DSM supplementation, confirming our hypothesis that the presence of this bacterium may decrease the expression of TRPV1 activation by ethanol. In addition, an ELISA assay showed decreased substance P levels upon DSM supplementation. The literature also shows that other lactobacilli, such as Lactobacillus casei and Lactobacillus fermentum, inhibit the expression of TRPV1 and have intestinal therapeutic effect [52,53], and L. fermentum also decreases the levels of substance P to exert its gastroprotective effect [19].

The literature shows that the binding of SP to neurokinin type I receptor and its activation is necessary for the deleterious actions of this neurokinin, and that NK1 receptor antagonists have gastroprotective activity in the ethanol-induced injury [9,11]. We also assessed whether L. reuteri could modulate the SP receptor as a protection against ethanol action. Thus, as already described in the literature, administration of SP along with $50 \%$ ethanol increases the lesion caused by ethanol alone, and NK1 antagonists can effectively reverse the lesion generated [9]. However, in our study, pretreatment with DSM was not able to reverse the lesion caused by this agent, whereas the NK1 antagonist, WIN 62,577, significantly reduced the area of gastric lesion. Thus, DSM probably does not act by modulating this receptor in its gastroprotective effect. In this way, we suggest that the 
reduction of substance P levels in treated animals may be due to inhibition of TRPV1 receptor activation that this probiotic promoted in our study.

This study and previous studies showed that biomarkers of oxidative stress, such as levels of free radicals and MDA, are significantly increased by treatment with $50 \%$ ethanol $[29,54]$. DSM supplementation reduced levels of lipid peroxidation, causing a decrease in MDA concentration, and this protective effect was reversed upon treatment with a TRPV1 agonist. Pretreatment with DSM did not decrease MDA concentrations when SP was coadministered with ethanol to damage the gastric tissue, in agreement with previous results in this study. In our findings, ethanol increased the NOx levels, which are metabolites of nitric oxide (circulating nitrites and nitrates) in the gastric mucosa. DSM pretreatment maintained normal NOx levels, but this protective effect was reversed upon treatment with a TRPV1 agonist, and DSM could not reduce the NOx levels alongside SP administration. Previous studies show that acute ethanol administration increases neutrophil nitric oxide production through activating iNOS (inducible NO synthase), agreeing with our NOx results [55,56]. In addition, other studies with probiotics demonstrated decreased iNOS activation, and consequently, nitrite levels, in the probiotics' beneficial effects in different models $[20,52,53]$.

An important defense mechanism that organisms possess for maintaining the gastric mucosa against free radicals is enzymatic and nonenzymatic antioxidant systems [57]. An imbalance between the protective and damaging factors in the gastric mucosa decreases the defense capacity of the stomach, leading to gastric injury [54]. Superoxide dismutase is a metalloenzyme that catalyzes the reaction that transforms superoxide anions into hydrogen peroxide, playing an important role in eliminating reactive oxygen species, and ethanol treatment decreases the activity of this enzyme [12,58]. In this study, ethanol administration decreased SOD levels, and the pretreatment with DSM increased SOD activity despite ethanol-induced gastric damage. In addition, ethanol reduces the concentration of nonprotein sulfhydryl groups by depleting glutathione, a protective factor of the gastric mucosa [59].

Another important antioxidant process occurs through glutathione peroxidase, which converts glutathione to oxidized glutathione, and this process reduces $\mathrm{H}_{2} \mathrm{O}_{2}$ to $\mathrm{H}_{2} \mathrm{O}$ and hydroperoxide lipids into stable alcohols, playing an important role in protecting cells against the effects of hydrogen peroxide. Glutathione reductase reduces oxidized glutathione to GSH [58,60]. In agreement with results of previous studies, ethanol decreased GSH concentration in the gastric mucosa, and supplementation with DSM maintained normal levels of this protective mucosal factor of the mucosa upon gastric injury induced by ethanol.

The activation of the TRPV1 receptor with its ultrapotent agonist, RTX, overcame the protective effect of DSM pretreatment on levels of SOD and GSH in gastric tissue, showing that these antioxidant factors are also related to the action of DSM via TRPV1. However, DSM did not inhibit the depletion of antioxidant factors induced by coadministering SP and ethanol. These results reinforce our hypothesis that decreased oxidative stress and increased gastric protection by DSM in ethanol-induced gastric injury occurred through the TRPV1 receptor, and not through the receptor of SP.

Mucus secretion and gastric acid production are important homeostatic factors that maintain mucosal integrity, and an imbalance in this homeostasis can lead to ulceration [61-63]. The literature shows that excess alcohol can significantly reduce the layer of protective mucus, reducing its ability to defend against aggressive agents [64]. In this study, ethanol was reduced the mucus layer of the gastric wall, and pretreatment with DSM prevented this mucus reduction in ethanol-injured animals.

Studies show that levels of SP are elevated in gastric lesions and that tachykinin may increase gastric acid secretion, which can aggravate the lesions, since it is an excitatory gastrointestinal hormone [19,65]. In our study, as already discussed, ethanol increased levels of SP, and also increased acid secretion. Furthermore, supplementation with DSM did not appear to modify the normal volume of gastric secretion, $\mathrm{pH}$, or total acidity in gastric mucosa of mice. 


\section{Conclusions}

In summary, our findings showed that L. reuteri DSM 17938 supplementation protected the gastric mucosa from ethanol-induced gastric injury in mice. This activity was mediated by reducing oxidative stress and maintaining antioxidant activity, despite decreased SP levels. Our results supported the hypothesis that DSM may act by decreasing TRPV1 receptor expression, inhibiting the effects of ethanol-mediated TRPV1, thereby decreasing reactive oxygen species levels in the gastric mucosa. Future studies are required to confirm the model generated in this work.

Author Contributions: A.P.O., L.K.M.S., T.S.L.A., and S.d.A. performed the majority of the experiments in vivo and ex vivo; R.O.S. and D.M.P. contributed to the data analysis; C.S.M. and G.A.d.C.B. performed the histopathological analysis; A.P.O., K.M.N., and F.B.M.S. wrote the manuscript; J.V.R.M. and M.H.L.P.S. reviewed and edited the manuscript; J.V.R.M. contributed for the funding acquisition.

Funding: The study obtained financial support from CAPES-Brazil and the National Council of Technological and Scientific Development-CNPq. Medeiros, Brito, and Souza are recipients of CNPq fellowships.

Acknowledgments: The authors gratefully acknowledge the financial support from CNPq (Brazil) and Research foundation for the State of Piaul-FAPEPI.

Conflicts of Interest: The authors declare no conflict of interest. The funders had no role in the design of the study; in the collection, analyses, or interpretation of data; in the writing of the manuscript, or in the decision to publish the results.

\section{References}

1. World Health Organization. Global Status Report on Alcohol and Health 2018; World Health Organization: Geneva, Switzerland, 2018; pp. 38-84. ISBN 978-92-4-156563-9.

2. Li, G.; Zhu, L.; Cao, Z.; Wang, J.; Zhou, F.; Wang, X.; Li, X.; Nie, G. A New Participant in the Pathogenesis of Alcoholic Gastritis: Pyroptosis. Cell Physiol. Biochem. 2018, 49, 406-418. [CrossRef] [PubMed]

3. Rubbens, J.; Brouwers, J.; Wolfs, K.; Adams, E.; Tack, J.; Augustijns, P. Ethanol concentrations in the human gastrointestinal tract after intake of alcoholic beverages. Eur. J. Pharm. Sci. 2016, 86, 91-95. [CrossRef] [PubMed]

4. Abdul-Rahman, A.K.; Card, T.R.; Grainge, M.J.; Fleming, K.M. All-cause and cause-specific mortality rates of patients treated for alcohol use disorders: A meta-analysis. Subst. Abuse 2018. [CrossRef] [PubMed]

5. Sommansson, A.; Saudi, W.S.W.; Nylander, O.; Sjöblom, M. The Ethanol-Induced Stimulation of Rat Duodenal Mucosal Bicarbonate Secretion In Vivo Is Critically Dependent on Luminal $\mathrm{Cl}^{-}$. PLoS ONE 2014, 9, e102654. [CrossRef] [PubMed]

6. Pan, J.S.; He, S.Z.; Xu, H.Z.; Zhan, X.J.; Yang, X.N.; Xiao, H.M.; Shi, H.X.; Ren, J.L. Oxidative stress disturbs energy metabolism of mitochondria in ethanol-induced gastric mucosa injury. World J. Gastroenterol. 2008, 14, 5857-5867. [CrossRef] [PubMed]

7. Lucetti, L.T.; Silva, R.O.; Santana, A.P.M.; de Melo Tavares, B.; Vale, M.L.; Soares, P.M.G.; Lima Júnior, F.J.B.; Magalhães, P.J.C.; Cunha, F.Q.; Ribeiro, R.A.; et al. Nitric oxide and hydrogen sulfide interact when modulating gastric physiological functions in rodents. Dig. Dis. Sci. 2017, 62, 93-104. [CrossRef] [PubMed]

8. Tarnawski, A.S.; Ahluwalia, A.; Jones, M.K. Angiogenesis in gastric mucosa: An important component of gastric erosion and ulcer healing and its impairment in aging. J. Gastroenterol. Hepatol. 2014, 29, 112-123. [CrossRef]

9. Gazzieri, D.; Trevisani, M.; Springer, J.; Harrison, S.; Cottrell, G.S.; Andre, E.; Nicoletti, P.; Massi, D.; Zecchi, S.; Nosi, D.; et al. Substance P released by TRPV1-expressing neurons produces reactive oxygen species that mediate ethanol-induced gastric injury. Free Radic. Biol. Med. 2007, 43, 581-589. [CrossRef]

10. Hayashi, H.; Nishiyama, K.; Majima, M.; Katori, M.; Saigenji, K. Role of endogenous substance P in ethanol-induced mucosal damage in the rat stomach. J. Gastroenterol. 1996, 31, 314-322. [CrossRef]

11. Karmeli, F.; Eliakim, R.; Okon, E.; Rachmilewitz, D. Gastric Mucosal Damage by Ethanol Is Mediated by Substance P and Prevented by Ketotifen, a Mast Cell Stabilizer. Gastroenterology 1991, 100, 1206-1216. [CrossRef] 
12. Getzoff, E.D.; Tainer, J.A.; Weiner, P.K.; Kollman, P.A.; Richardson, P.J.S.; Richardson, D.C. Electrostatic recognition between superoxide and copper, zinc superoxide dismutase. Nature 1983, 306, 287-290. [CrossRef] [PubMed]

13. Kwiecien, S.; Jasnos, K.; Magierowski, M.; Sliwowski, Z.; Pajdo, R.; Brzozowski, B.; Mach, T.; Wojcik, D.; Brzozowski, T. Lipid peroxidation, reactive oxygen species and antioxidative factors in the pathogenesis of gastric mucosal lesions and mechanism of protection against oxidative stress-induced gastric injury. $J$. Physiol. Pharmacol. 2014, 65, 613-622. [PubMed]

14. Farrell, C.P.; Morgan, M.; Rudolph, D.S.; Hwang, A.; Albert, N.E.; Valenzano, M.C.; Wang, X.; Mercogliano, G.; Mullin, J.M. Proton Pump Inhibitors Interfere With Zinc Absorption and Zinc Body Stores. Gastroenterol. Res. 2011, 4, 243-251. [CrossRef] [PubMed]

15. Hill, C.; Guarner, F.; Reid, G.; Gibson, G.R.; Merenstein, D.J.; Pot, B.; Morelli, L.; Canani, R.B.; Flint, H.J.; Salminen, S.; et al. Expert consensus document. The International Scientific Association for Probiotics and Prebiotics consensus statement on the scope and appropriate use of the term probiotic. Nat. Rev. Gastroenterol. Hepatol. 2014, 11, 506-514. [CrossRef] [PubMed]

16. Azmi, L.; Gupta, S.S.; Shukla, I.; Kant, P.; Upreti, D.K.; Rao, C.V. Gastro protective effects of usnea longissima metabolites on probiotic Lactobacillus casei. Int. J. Pharmacogn. 2016, 3, 140-148. [CrossRef]

17. Liu, C.F.; Hu, C.L.; Chiang, S.S.; Tseng, K.C.; Yu, R.C.; Pan, T.M. Beneficial Preventive Effects of Gastric Mucosal Lesion for Soy—Skim Milk Fermented by Lactic Acid Bacteria. J. Agric. Food Chem. 2009, 57, 4433-4438. [CrossRef]

18. Senol, A.; Isler, M.; Karahan, A.G.; Kilic, G.B.; Kuleasan, H.; Kaya, S.; Keskin, M.; Goren, I.; Saritas, U.; Aridogan, B.C.; et al. Preventive effect of probiotics and $\alpha$-tocopherol on ethanol-induced gastric mucosal injury in rats. J. Med. Food 2011, 14, 173-179. [CrossRef]

19. Suo, H.; Zhao, X.; Qian, Y.; Sun, P.; Zhu, K.; Li, J.; Sun, B. Lactobacillus fermentum Suo attenuates $\mathrm{HCl} / \mathrm{Ethanol}$ induced gastric injury in mice through its antioxidant effects. Nutrients 2016, 8, 155. [CrossRef]

20. Wagnerberger, S.; Spruss, A.; Kanuri, G.; Stahl, C.; Schröder, M.; Vetter, W.; Bischoff, S.C.; Bergheim, I. Lactobacillus casei Shirota protects from fructose-induced liver steatosis: A mouse model. J. Nutr. Biochem. 2013, 24, 531-538. [CrossRef]

21. Rosander, A.; Connolly, E.; Roos, S. Removal of antibiotic resistance gene-carrying plasmids from Lactobacillus reuteri ATCC 55730 and characterization of the resulting daughter strain, L. reuteri DSM 17938. Appl. Environ. Microbial. 2008, 74, 6032-6040. [CrossRef]

22. Casas, I.A.; Dobrogosz, W.J. Validation of the Probiotic Concept: Lactobacillus reuteri Confers Broad-spectrum Protection against Disease in Humans and Animals. Microb. Ecol. Health Dis. 2000, 12, 247-285. [CrossRef]

23. Fatheree, N.Y.; Liu, Y.; Taylor, C.M.; Hoang, T.K.; Cai, C.; Rahbar, M.H.; Hessabi, M.; Ferris, M.; McMurtry, V.; Wong, C.; et al. Lactobacillus reuteri for infants with colic: A double-blind, placebo-controlled, randomized clinical trial. J. Pediatr. 2017, 191, 170-178. [CrossRef] [PubMed]

24. Szymański, H.; Szajewska, H. Efficacy of Lactobacillus Reuteri DSM 17938 for the Treatment of Acute Gastroenteritis in Children: Protocol of a Randomized Controlled Trial. JMIR Res. Protoc. 2017, 6, e164. [CrossRef] [PubMed]

25. Coccorullo, P.; Strisciuglio, C.; Martinelli, M.; Miele, E.; Greco, L.; Staiano, A. Lactobacillus reuteri (DSM 17938) in infants with functional chronic constipation: A double-blind, randomized, placebo-controlled study. J. Pediatr. 2010, 157, 598-602. [CrossRef]

26. Francavilla, R.; Lionetti, E.; Castellaneta, S.; Ciruzzi, F.; Indrio, F.; Masciale, A.; Fontana, C.; La Rosa, M.M.; Cavallo, L.; Francavilla, A. Randomised clinical trial: Lactobacillus reuteri DSM 17938 vs. placebo in children with acute diarrhea-A double-blind study. Aliment. Pharmacol. Ther. 2012, 36, 363-369. [CrossRef]

27. Haileselassie, Y.; Navis, M.; Vu, N.; Qazi, K.R.; Rethi, B.; Sverremark-Ekström, E. Postbiotic modulation of retinoic acid imprinted mucosal-like dendritic cells by probiotic Lactobacillus reuteri 17938 in vitro. Front. Immunol. 2016, 7, 1-11. [CrossRef]

28. Perez-burgos, A.; Wang, L.; Neufeld, K.A.M.; Mao, Y.K.; Ahmadzai, M.; Janssen, L.J.; Stanisz, A.M.; Bienenstock, J.; Kunze, W.A. The TRPV1 channel in rodents is a major target for antinociceptive effect of the probiotic Lactobacillus reuteri DSM 17938. J. Physiol. 2015, 593, 3943-3957. [CrossRef] 
29. Medeiros, J.V.R.; Bezerra, V.H.; Gomes, A.S.; Barbosa, A.L.R.; Lima-Júnior, R.C.P.; Soares, P.M.G.; Brito, G.A.C.; Ribeiro, R.A.; Cunha, F.Q.; Souza, M.H.L.P. Hydrogen sulfide prevents ethanol-induced gastric damage in mice: Role of ATP-sensitive potassium channels and capsaicin-sensitive primary afferent neurons. J. Pharmacol. Exp. Ther. 2009, 330, 764-770. [CrossRef]

30. Tramontana, M.; Renzi, D.; Panerai, C.; Surrenti, C.; Nappi, F.; Abelli, L.; Evangelista, S. Capsaicin-like effect of resiniferatoxin in the rat stomach. Neuropeptides 1994, 26, 29-32. [CrossRef]

31. Laine, L.; Weinstein, W.M. Histology of alcoholic hemorrhagic "gastritis": A prospective evaluation. Gastroenterology 1988, 94, 1254-1262. [CrossRef]

32. Buckinx, R.; Nassauw, L.V.; Avula, L.R.; Alpaerts, K.; Adriaensen, D.; Timmermans, J.P. Transient receptor potential vanilloid type 1 channel (TRPV1) immunolocalization in the murine enteric nervous system is affected by the targeted C-terminal epitope of the applied antibody. J. Histochem. Cytoch. 2013, 61, 421-432. [CrossRef] [PubMed]

33. Helps, S.C.; Thornton, E.; Kleinig, T.J.; Manavis, J.; Vink, R. Automatic nonsubjective estimation of antigen content visualized by immunohistochemistry using color deconvolution. Appl. Immunohistochem. Mol. Morphol. 2012, 20, 82-90. [CrossRef] [PubMed]

34. Ruifrok, A.C.; Johnston, D.A. Quantification of Histochemical Staining by Color Deconvolution. Anal. Quant. Cytol. Histol. 2001, 23, 291-299. [PubMed]

35. Ma, J.; Altomare, A.; de la Monte, S.; Tong, M.; Rieder, F.; Fiocchi, C.; Behar, J.; Shindou, H.; Biancani, P.; Harnett, K.M. HCl-induced inflammatory mediators in esophageal mucosa increase migration and production of $\mathrm{H}_{2} \mathrm{O}_{2}$ by peripheral blood leukocytes. Am. J. Physiol. Gastrointest. Liver Physiol. 2010, 299, 791-798. [CrossRef] [PubMed]

36. Uchiyama, M.; Mihara, M. Determination of malonaldehyde precursor in tissues by thiobarbituric acid test. Anal. Biochem. 1978, 86, 271-278. [CrossRef]

37. Green, L.C.; Wagner, D.A.; Glogowski, J.; Skipper, P.L.; Wishnok, J.S.; Tannenbaum, S.R. Analysis of nitrate, nitrite and (15N) nitrate in biological fluids. Anal. Biochem. 1982, 126, 131-138. [CrossRef]

38. Sedlak, J.; Lindsay, R.H. Estimation of total, protein-bound, and nonprotein sulfhydryl groups in tissue with Ellman's reagent. Anal. Biochem. 1968, 25, 192-205. [CrossRef]

39. Das, K.; Samanta, L.; Chainy, G.B.N. A modified spectrophotometric assay of superoxide dismutase using nitrite formation by superoxide radicals. Indian J. Biochem. Biophys. 2000, 37, 201-204.

40. Corne, S.J.; Morrissey, S.M.; Woods, R.J. Proceedings: A method for the quantitative estimation of gastric barrier mucus. J. Physiol. 1974, 242, 116-117.

41. Shay, M.; Kamarov, S.A.; Fels, D.; Meranze, D.; Gruenstein, H.; Siplet, H. A simple method for the uniform production of gastric ulceration in the rats. Gastroenterology 1945, 5, $43-61$.

42. Gamallat, Y.; Meyiah, A.; Kuugbee, E.D.; Hago, A.M.; Chiwala, G.; Awadasseid, A.; Bamba, D.; Zhang, X.; Shang, X.; Luo, F.; et al. Lactobacillus rhamnosus induced epithelial cell apoptosis, ameliorates inflammation and prevents colon cancer development in an animal model. Biomed. Pharmacother. 2016, 83, 536-541. [CrossRef] [PubMed]

43. Štofilová, J.; Langerholc, T.; Botta, C.; Treven, P.; Gradišnik, L.; Salaj, R.; Šoltésová, A.; Bertková, I.; Hertelyová, Z.; Bomba, A. Cytokine production in vitro and in rat model of colitis in response to Lactobacillus plantarum LS/07. Biomed. Pharmacother. 2017, 94, 1176-1185. [CrossRef] [PubMed]

44. Walsham, A.D.S.; Mackenzie, D.A.; Cook, V.; Wemyss-holden, S.; Hews, C.L.; Juge, N.; Schüller, S. Lactobacillus reuteri Inhibition of Enteropathogenic Escherichia coli Adherence to Human Intestinal Epithelium. Front. Microbiol. 2016, 7, 244. [CrossRef] [PubMed]

45. Dore, M.P.; Cuccu, M.; Pes, G.M.; Manca, A.; Graham, D.Y. Lactobacillus reuteri in the treatment of Helicobacter pylori infection. Intern. Emerg. Med. 2014, 9, 649-654. [CrossRef] [PubMed]

46. Liu, Y.; Tran, D.Q.; Fatheree, N.Y.; Rhoads, J.M. Lactobacillus reuteri DSM 17938 differentially modulates effector memory T cells and Foxp $3^{+}$regulatory T cells in a mouse model of necrotizing enterocolitis. Am. J. Physiol. Gastrointest. Liver Physiol. 2014, 307, 177-186. [CrossRef]

47. Liu, Y.; Fatheree, N.Y.; Mangalat, N.; Rhoads, J.M. Lactobacillus reuteri strains reduce incidence and severity of experimental necrotizing enterocolitis via modulation of TLR4 and NF- $\mathrm{kB}$ signaling in the intestine. Am. J. Physiol. Gastrointest. Liver Physiol. 2012, 302, 608-617. [CrossRef] 
48. Lam, E.K.Y.; Tai, E.K.K.; Koo, M.W.L.; Wong, H.P.S.; Wu, W.K.K.; Yu, L.; So, W.H.L.; Woo, P.C.Y.; Cho, C.H. Enhancement of gastric mucosal integrity by Lactobacillus rhamnosus GG. Life Sci. 2007, 80, 2128-2136. [CrossRef]

49. Guslandi, M. Effects of ethanol on the gastric mucosa. Dig. Dis. 1987, 5, 21-32. [CrossRef]

50. Choi, Y.J.; Kim, N.; Lee, J.Y.; Nam, R.H.; Seo, J.H.; Lee, S.; Kim, H.J.; Choi, Y.J.; Lee, H.S.; Lee, D.H. Gastroprotective Effects of PMK-S005 against Ethanol-Induced Acute Gastric Damage in Rats. Gut Liver 2016, 10, 348-355. [CrossRef]

51. Batran, R.A.; Al-bayaty, F.; Al-obaidi, M.M.J.; Abdualkader, A.M.; Hadi, H.A.; Ali, H.M.; Abdulla, M.A. In Vivo Antioxidant and Antiulcer Activity of Parkia speciosa Ethanolic Leaf Extract against Ethanol-Induced Gastric Ulcer in Rats. PLoS ONE 2013, 8, e64751. [CrossRef]

52. Zhao, X.; Suo, H.Y.; Qian, Y.; Li, G.J.; Liu, Z.H.; Li, J. Therapeutic effects of Lactobacillus casei Qian treatment in activated carbon-induced constipated mice. Mol. Med. Rep. 2015, 12, 3191-3199. [CrossRef] [PubMed]

53. Suo, H.; Zhao, X.; Qian, Y.; Li, G.; Liu, Z.; Xie, J.; Li, J. Therapeutic Effect of Activated Carbon-Induced Constipation Mice with Lactobacillus fermentum Suo on Treatment. Int. J. Mol. Sci. 2014, 15, 21875-21895. [CrossRef] [PubMed]

54. Souza, L.K.M.; Nicolau, L.A.D.; Sousa, N.A.; Araújo, T.S.L.; Sousa, F.B.M.; Costa, D.S.; Souza, F.M.; Pacífico, D.M.; Martins, C.S.; Silva, R.O.; et al. Diminazene aceturate, an angiotensin-converting enzyme II activator, prevents gastric mucosal damage in mice: Role of the angiotensin-(1-7)/Mas receptor axis. Biochem. Pharmacol. 2016, 112, 50-59. [CrossRef] [PubMed]

55. Deng, X.S.; Deitrich, R.A. Ethanol metabolism and effects: Nitric oxide and its interaction. Curr. Clin. Pharmacol. 2007, 2, 145-153. [CrossRef] [PubMed]

56. Gago, B.; Nyström, T.; Cavaleiro, C.; Rocha, B.S.; Barbosa, R.M.; Laranjinha, J.; Lundberg, J.O. The potent vasodilator ethyl nitrite is formed upon reaction of nitrite and ethanol under gastric conditions. Free Radic. Biol. Med. 2008, 45, 404-412. [CrossRef] [PubMed]

57. Halliwell, B.; Aeschbach, R.; Loliger, J.; Aruoma, O.I. The characterization of antioxidants. Food Chem. Toxicol. 1995, 33, 601-617. [CrossRef]

58. Bhattacharyya, A.; Chattopadhyay, R.; Mitra, S.; Crowe, S.E. Oxidative stress: An essential factor in the pathogenesis of gastrointestinal mucosal diseases. Physiol. Rev. 2014, 94, 329-354. [CrossRef] [PubMed]

59. Loguercio, C.; Taranto, D.; Beneduce, F.; Blanco, C.V.; Vincentiis, A.; Nardi, G.; Romano, M. Glutathione prevents ethanol induced gastric mucosal damage and depletion of sulfhydryl compounds in humans. Gut 1983, 34, 161-165. [CrossRef]

60. Bompart, G.J.; Prévot, D.S.; Bascands, J.L. Rapid automated analysis of glutathione reductase, peroxidase, and S-transferase activity: Application to cisplatin-induced toxicity. Clin. Biochem. 1990, 23, 501-504. [CrossRef]

61. Carvalho, N.S.; Silva, M.M.; Silva, R.O.; Nicolau, L.A.D.; Sousa, F.B.M.; Damasceno, S.R.B.; Silva, D.A.; Barbosa, A.L.R.; Leite, J.R.S.A.; Medeiros, J.V.R. Gastroprotective Properties of Cashew Gum, a Complex Heteropolysaccharide of Anacardium occidentale, in Naproxen-Induced Gastrointestinal Damage in Rats. Drug Dev. Res. 2015, 76, 143-151. [CrossRef]

62. Ermund, A.; Schütte, A.; Johansson, M.E.V.; Gustafsson, J.K.; Hansson, G.C. Studies of mucus in mouse stomach, small intestine, and colon. I. Gastrointestinal mucus layers have different properties depending on location as well as over the Peyer's patches. Am. J. Physiol. Gastrointest. Liver Physiol. 2013, 305, 341-347. [CrossRef] [PubMed]

63. Hersey, S.J.; Sachs, G. Gastric acid secretion. Physiol. Rev. 1995, 75, 155-189. [CrossRef] [PubMed]

64. Hung, C.R.; Neu, S.L. Acid-induced gastric damage in rats is aggravated by starvation and prevented by several nutrients. J. Nutr. 1997, 127, 630-636. [CrossRef] [PubMed]

65. Yokotani, K.; Fujiwara, M. Effects of substance P on cholinergically stimulated gastric acid secretion and mucosal blood flow in rats. J. Pharmacol. Exp. Ther. 1985, 232, 826-830. [PubMed]

(C) 2019 by the authors. Licensee MDPI, Basel, Switzerland. This article is an open access article distributed under the terms and conditions of the Creative Commons Attribution (CC BY) license (http:/ / creativecommons.org/licenses/by/4.0/). 